\title{
Determination of Extracellular Hydrolytic Enzyme Production Capabilities of Acidithiobacillus Bacteria Isolated from Awasppi River in Sulaymaniyah, Iraq and 16S rDNA Analysis
}

\author{
Ghalib Abdalla SHAREF, Kerem ÖZDEMIR*, Metin ERTAS
}

Department of Molecular Biology and Genetics, Faculty of Science, Van Yuzuncu Yil University, Van, Turkey

\begin{abstract}
Received: 18.12 .2017
Accepted: 14.02 .2018

Available online: 08.03 .2018

Published: 30.06 .2018

Abstract: In this study, the 16S rDNA gene regions' phylogenetic positions based on the sequence analysis were determined by examining some hydrolytic extracellular enzyme activities of the Acidithiobacillus bacteria isolated from the water and mud samples obtained from the Awasspi River in Sulaymaniyah province, northern Iraq and from the Darzilais sulphur cave in Sangaw district. While the catalase activity of the isolates was positive; lipase, protease, xylanase, and amylase activities were found to be negative.

Genomic DNAs of the isolates were isolated and 16S rDNA gene region was realized with PCR amplification. To determine the distance between the species, Maximum Likelihood algorithm was used to form a phylogenetic tree. It was observed that gene strands belonging to Acidithiobacillus species acquired from NCBI and 2 isolates we used in our study clustered with a strong homology and their genetic positions were revealed.
\end{abstract}

Keywords: Acidithiobacillus, Sulaymaniyah, Enzyme, $16 \mathrm{~S}$ rDNA

\section{Awa Sppi Nehri'nden (Süleymaniye-Irak) İzole Edilen Acidithiobacillus Cinsi Bakterilerin Ektraselüler Hidrolitik Enzim Üretme Kabiliyetlerinin Belirlenmesi ve 16S rDNA Analizi}

\begin{abstract}
Özet: Bu araştırmada, Kuzey Irak'ın Süleymaniye şehrinde bulunan Awasppi nehrinden ve Sangaw'daki Darzilais sülfür kaynaklı mağaradan alınan su ve çamur örneklerinden izole edilen Acidithiobacillus bakterilerinin bazı hidrolitik ektraselüler enzim aktiviteleri incelenerek, 16S rDNA gen bölgelerinin sekans analizi temeline dayalı filogenetik pozisyonları belirlenmiştir. İzolatların katalaz aktivitesi pozitif iken, lipaz, proteaz, ksilanaz ve amilaz aktivitesi negatif olarak belirlenmiştir.

İzolatların Genomik DNA'ları izole edilerek 16S rDNA gen bölgesi PZR amplifikasyonu ile gerçekleştirilmiştir. Türler arasındaki uzaklığı belirlemek için Maximum Likelihood algoritması kullanılarak oluşturulan filogenetik ağaç NCBI'dan elde edilmiş Acidithiobacillus türlerine ait gen dizileri ve çalışmamızda kullandığımız 2 izolat güçlü bir homoloji ile kümelendiği gözlemlenerek genetik pozisyonları ortaya konmuştur. Karşılaştırmalı 16S rDNA gen dizisi analizi sonucunda, G1 izolatının Acidithiobacillus thiooxidans'a \% 99 benzerlik gösterdiği ve G2 izolatının Acidithiobacillus ferrooxidans'a \% 99 benzerlik gösterdiği belirlenmiştir.
\end{abstract}

Anahtar kelimeler: Acidithiobacillus, Süleymaniye, Enzim, 16S rDNA

\section{Giriş}

Asidofilik mikroorganizmalar, yer kabuğunda bulunan değerli metallerin depolanmasında ve ayrıştırılmasında önemli bir role sahip olduklarından, endüstriyel açıdan önem taşımaktadırlar (Valenzuela et al., 2006). Antik çağlardan beri mikroorganizmalar ağır metallerin yer kabuğu üzerinde depolanmasında ve çözünmesinde önemli bir role sahiptir. Bu aktivitenin önemli bir kısmı demir ve sülfür döngüsü ile ilgilidir. Anaerobik sülfat indirgeyici bakteriler çeşitli metallerle reaksiyona girerek çözünmeyen sülfürlü minerallerin $\left(\mathrm{Fe}_{2} \mathrm{~S}_{2}, \mathrm{ZnS}, \mathrm{CuFeS}_{2}\right.$ gibi) ve cevher yataklarının oluşmasını sağlarlar. Tersi bir reaksiyonda bu sülfürlü mineraller, aerobik sülfür oksitleyici mikroorganizmalar için elektron vericisi olarak görev yapar ve metal sülfatlara dönüşürler. Metal sülfatların çoğunun çözünürlüğü yüksek olduğu için bu reaksiyon, maden ve mineral kaynaklarından metallerin kazanımında/uzaklaştırılmasında kullanılır (Rawlings,
2005). Çeşitli mikroorganizmaların madenlerdeki ağır metalleri çözünebilir hale getirebilme özellikleri biyomadencilik endüstrisinin gelişimine yol açmıştır (Rawlings, 1997).

Acidithiobacillus cinsi bakteriler, değerli metallerin sülfürlü minerallerden çıarılmasındaki etkili rolleri sebebiyle "biyomadencilik" alanında kullanılırlar. Bu bakteriler asidofilik, gram-negatif ve çubuk şekillidirler. Hem mezofilik hem de termofilik olabilirler (Bellenberg et al., 2015). $\mathrm{CO}_{2}$ fiksasyonu yapabildikleri için, organik karbon kaynağından bağımsız gelişebilirler. Bu özelliklerinden dolayı organik karbon konsantrasyonunun çok düşük olduğu maden atıkları ekosisteminde bile hayatta kalabilirler. Günümüzde bilinen 6 çeşit Acidithiobacillus cinsi bakteri sırasıyla $A$. thiooxidans, A. albertensis, A. caldus, A. ferrooxidans, A. ferrivorans ve $A$. ferridurans olarak sayllabilir (Hedrich \& Johnson, 2013). Tüm türleri inorganik sülfür bileşiklerini 
elektron donörü olarak kullanırlar. Bu yüzden, tüm dünyada metal sülfit yataklarında (Karavaiko et al., 2003), sülfit yataklarla birleşmiş su kaynaklarında (Gonzalez-Toril, Llobet-Brossa, Casamayor, Amann, \& Amils, 2003) ve deniz suyunda bulunurlar (Kamimura, Higashino, Moriya, \& Sugio, 2003).

Günümüze kadar yapılan çalışmalarda genelde, sülfürlü minerallerin kimyasal liç sırasındaki çözünme mekanizmaları ve kinetikleri incelenmiştir. Asidofilik bakterilerin enzim aktiviteleri ile mevcut çalışmalar oldukça azdır. Bu çalışmada Kuzey Irak'ın Süleymaniye şehrinde bulunan Darzilais mağarası ve Awaseppi sülfür kaynaklarında asidofilik bakterilerin izolasyonu, extraselüler hidrolitik enzim aktivitelerinin belirlenmesi ve $16 \mathrm{~S}$ rDNA gen bölgesi ile teşhislerinin yapılması amaçlanmıştır.

\section{Materyal ve Yöntem}

\subsection{Materyal}

$\mathrm{Bu}$ çalışmada Irak-Süleymaniye şehrinde bulunan Awasppi nehrinden alınan su numunelerinden ve Sangaw Darzilais'teki sülfür kaynaklı mağara topraklarından izole edilen Acidithiobacillus cinsi bakteriler materyal olarak kullanılmıştır.

\subsection{Yöntem}

\subsubsection{Bakteri İzolasyonu ve Saflaştırılması}

Bakterilerin izolasyonu sıvı Starkey mineral basal salt medium besi ortamında $30{ }^{\circ} \mathrm{C}^{\prime}$ de 2 gün çalkalamalı inkübatörde bekletilerek gerçekleştirilmiştir. Saflaştırma işlemi Thiobacillus Agar M788 medium ortamında gerçekleştirilmiş ve $30{ }^{\circ} \mathrm{C}^{\prime}$ de 5 gün inkübasyona bırakılmıştır.

\subsubsection{Morfolojik Karakterizasyon}

Acidithiobacillus cinsinin morfolojik özellikleri sulfuroxidizer medium agar besi ortaminda 7 gün inkübasyon sonrası stereo mikroskop altında gözlemlenip fotoğraflanmıştır. Daha sonra gram boyama yapılarak bakterilerin hücre duvarı tipi belirlenmiştir.

\subsubsection{Biyokimyasal Testler}

Acidithiobacillus cinsinin biyokimyasal karakterizasyon testleri, 48 saatlik kültür kullanılarak gerçekleştirilmiştir. İzolatların ekstraselüler hidrolitik enzimler olan amilaz, ksilanaz, lipaz, proteaz ve katalaz aktivitesine bakılmıştır. Bakteriyel tanımlama işlemi için morfolojik ve boyanma sonuçları ile birlikte biyokimyasal test sonuçları da anahtardır. Bergey's Manual of Determinative Bacteriology, Acidithiobacillus bakterilerinin sinıflandırılması ve tanımlanması için referans olarak kullanılmıştır (Holt, Krieg, Sneath, Staley, \& Williams, 1994).

\section{Amilaz}

İzolatların tümüne Amilaz enzimi üretimi için Thiobacillus Agar M788 medium hazırlandı ve içerisine $\% 2$ 'lik nişasta ilave edildi. $28{ }^{\circ} \mathrm{C}^{\prime}$ de 4 gün inkübe edildi. Besi yeri üzerine lügol damlatılarak etrafında açık renk zon oluşumu pozitif sonuç olarak değerlendirilmiştir.

\section{Ksilinaz}

İzolatların tümüne ksilinaz enzimi üretimi için Thiobacillus Agar M788 medium hazırlandı ve içerisine $\% 1$ 'lik ksilan ilave edildi. $28{ }^{\circ} \mathrm{C}^{\prime}$ de 4 gün inkübe edildi. Koloni etrafında açık renk zon oluşumu pozitif sonuç olarak değerlendirilmiştir.

\section{Proteaz}

İzolatların tümüne Proteaz enzimi üretimi için Thiobacillus Agar M788 medium hazırlandı ve içerisine \%1'lik yağsız süt tozu (Skim milk powder) ilave edildi. 28 ${ }^{\circ} C^{\prime}$ de 4 gün inkübe edildi. Besi yeri üzerinde etrafında açık renk zon oluşumu pozitif sonuç olarak değerlendirilmiştir.

\section{Lipaz}

İzolatların tümüne lipaz enzimi üretimi için Thiobacillus Agar M788 medium hazırlandı ve içerisine \%2'lik Tween 80 ilave edildi. $28{ }^{\circ} \mathrm{C}^{\prime}$ de 4 gün inkübe edildi. Besi yeri üzerine \%0,001'lik rodamin B ilave edildi. Koloniler etrafında açık renk zon oluşumu pozitif sonuç olarak değerlendirilmiştir.

\subsubsection{Genomik DNA İzolasyonu ve $16 \mathrm{~S}$ rDNA Gen Bölgesinin Amplifikasyonu}

Genomik DNA izolasyonu Ausubel et al. (1994) tarafından modifiye edilen metot ile gerçekleştirilmiştir. 16S rDNA polimeraz zincir reaksiyonu Thermal Cycler'da (MyGenie 96 Gradient Thermal Cycler, Kore) $0.2 \mathrm{ml}$ PCR tüplerinde gerçekleştirilmiştir. 16S rDNA gen bölgesi için evrensel primer olan 27f (5'-AGAGTT TGATCMTGGCTCAG-3') ve 1492R (5' TACGGYTACCTTGTTACGACTT) kullanılarak PZR amplifikasyonu gerçekleştirilmiştir (Lane, Stahl, Olsen, Heller, \& Pace, 1985).

\subsubsection{S rDNA Gen Bölgesinin Analizi}

16S rDNA bölgesi dizileme sonuçları Codon Code Aligner V.6.0.2 programı ile her suş için kromatogramlar tek tek incelenmiş ve zayıf nitelikli baz dizilerinin (belirsiz yani ' $\mathrm{N}$ ' kodlu birkaç baz) genellikle sekans başları ve sonlarındaki bölgelerinde kesilerek uzaklaştırılmış ve contiqler oluşturulmuştur. NCBI'da blast yapılarak her suşa yakın türlerin access kodları alınarak, hem veri tabanındaki yakın türlerle hem de kendi aralarında analiz edilmiştir. Daha sonra ClustalW programı ile korunmuş bölgeler kıyaslanarak, Mega7 programında Maximum Likelihood algaritmasında Jukes-Cantor metodu seçilmiş, Maksimum Likelihood filogenetik ağaçı oluşturulmuş ve izolatların evrimsel açıdan filogenetik pozisyonları belirlenmiştir.

\section{Bulgular}

İzole edilen 2 Acidithiobacillus bakterisi Thiobacillus Agar M788 besiyerinde küçük, kremsi veya soluk sarı renginde dairesel koloni oluşturmuşturlar. İzolatlara uygulanan gram boyama ile izolatların gram negatif hücre duvar tipine sahip oldukları belirlenmiştir.

Acidithiobacillus cinsinin biyokimyasal karakterizasyon testleri, 48 saatlik kültür kullanılarak gerçekleştirilmiştir. İzolatların ekstraselüler hidrolitik enzimler olan amilaz, ksilanaz, lipaz, proteaz ve katalaz aktivitesine bakılmıştır. İzolatlar amilaz, ksilanaz, proteaz aktivitesi göstermezken yalnızca katalaz aktivitesi göstermiştir. 

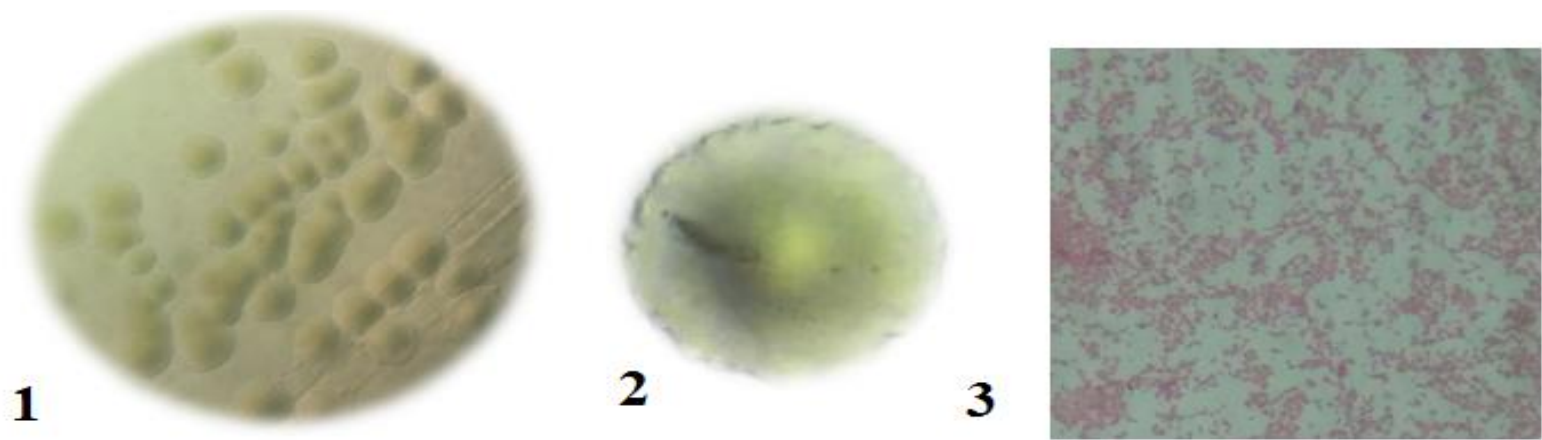

Şekil 1: Acidithiobacillus cinsi bakterilerin koloni yapıları (1-2) ve gram boyama (3) sonucunu gösteren görüntüler.

Bu 2 izolatın 16S rDNA dizisinin tanımlanması amaciyla PCR amplifikasyonu $27 \mathrm{~F}$ ve $1492 \mathrm{R}$ evrensel primerler gerçekleştirilmiştir. Codon Code Aligner V.6.0.2 programinı kullanarak, dizi cihazından alınan ham veriler düzenlenmiş ve birleştirilerek bir konsensus sekansı oluşturulmuştur. Benzerlik araştırması NCBI veri tabanlarinda bulunan Basic Local Alignment Search Tools (BLAST) programını kullanarak yapılmıştır.

İzolatların filogenetik konumunu belirlemek için, Şekil 2'deki referans Acidithiobacillus türlerinin 16S rDNA dizileri ile karşılaştırmalı olarak verilen filogenetik ağaç, Jukes-Cantor yöntemi ile Maksimum Olabilirlik algoritması ve Mega 7 paket programı kullanılarak oluşturulmuştur. Karşılaştırmalı 16S rDNA gen dizisi analizi sonucunda, G1 izolatının Acidithiobacillus thiooxidans'a \% 99 benzerlik gösterdiği ve G2 izolatının Acidithiobacillus ferrooxidans'a \% 99 benzerlik gösterdiği belirlenmiştir. Diş grup olarak Thermithiobacillus tepidarius seçilmiştir. Filogenetik ağaçta Acidithiobacillus cinsi bakteriler güçlü bir homoloji ile kümelenmiştir.

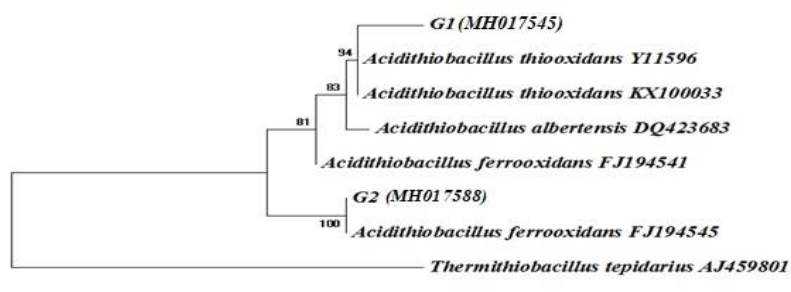

Şekil 2: $16 \mathrm{~S}$ rDNA analizi için Maksimum Likelihood algoritması ile oluşturula filogenetik ağaç (G1 ve G2 izolatının NCBI erişim numarası parantez içinde verilmiştir).

\section{Tartışma ve Sonuç}

Acidithiobacillus, özellikle pH'nın düşük olduğu, madencilik alanları, sıcak kükürt kaynakları ve biyoliçing işlemleri gibi geniş bir ortam yelpazesinde mevcut gibi görünmektedir (Khan, Haq, Hasan, Saeed, \& Ullah, 2012). Tiyobasil türlerini tahmin edebilmek için, sıvı ortamlı MPN (The Most Probable Number) tekniği yaygın olarak kullanılmaktadır ve yaygın olarak uygulanmaktadır. Yayma plak yöntemi ile Thiobacillus türlerinin izolasyonu ve yetiştirilmesi için önerilen Thiobacillus agar, diğer yöntemlere kıyasla benzer veya daha yüksek sayılarla sonuçlanan büyüyen kolonilerin keskin bir çözünürlüğünü elde etmek için bromokresol yeşil (BCG) eklenerek modifiye edilmiştir (Starosvetsky, Zukerman, \& Armon, 2012).

Çalışmamız Irak'taki Süleymaniye şehrinde bulunan Awasppi nehrinden ve Sangaw bölgesinde bulunan Darzilais'teki sülfür kaynaklı mağaradan toplanmış örneklerle gerçekleştirilmiştir. İzolasyon işlemi Starkey ortaminda gerçekleştirilmiş olup oldukça hassastır. Daha sonra Thiobacillus Agar M788 besiyerinde kolonilerin morfolojilerine bakılarak saflaştırma işlemi gerçekleştirilmiştir. Kolonilerin küçük ve benzer olması bu durumu oldukça zor hale getirmektedir.

Mezofilik organizmalardan izole edilen enzimler, esasen dar bir $\mathrm{pH}$, sıcaklık ve iyonik güç aralığında işlev görür ve bu da endüstriyel koşulları zorlayan teknolojik uygulamalarını zorlaştırır. Bu nedenle, asidite, alkalinite, tuzluluk, sıcaklık veya basınç aşırılıkları gibi zorlu çevresel koşullarda başarılı olabilen mikroorganizma aramak için kayda değer çabalar sarf edilmiştir. Ekstremofiller olarak adlandırılan bu mikroorganizmalar, aşırı koşullar altında işlev gören ve bu nedenle de büyük bir biyoteknolojik vaatte bulunan yeni enzimlerin değerli bir kaynağıdır (Van den Burg, 2003). Pakistan'ın Tarbela bölgesinden alınan toprak ve su örneklerinden izole edilen Acidithiobacillus thiooxidans bakterisine yönelik yapılan ekstraselüler hidrolitik enzim çalışmalarında nişasta hidroliz testi negatif olup katalaz testi pozitif sonuç göstermiştir (Khan et al., 2012). Saflaştırılan Acidithiobacillus bakterilerinin bazı ekstraselüler hidrolitik enzim aktiviteleri belirlenmiştir. İzolatların katalaz aktivitesi pozitifken, lipaz, proteaz, ksilanaz ve amilaz aktivitesi negatif olarak tespit edilmiştir. Bu araştırmada tanımlanan iki farklı izolatın morfolojik, fizyolojik özellikleri konu ile ilgili bilimsel literatürlerle uyum içerisindedir.

16S rRNA gen dizileme bakteriler arasındaki filogenetik ilişkilerin açıklanmasında, herhangi bir ortamdan izole edilen bakterilerin tanımlanmasinda 1980'lerden beri kullanılan güçlü bir tekniktir (Busse, Denner, \& Lubitz, 1996). 16S rRNA gen bölgesinin bakteriler arasında evrensel ve işlevinin sabit olması, korunaklı bölgelerin yanında türe özgü değişiklik gösteren bölgelerin varlığı, bakterileri cins veya tür seviyesinde tüm araştırmacılara açık veritabanlarını kullanarak tanımlanmasına imkân sağlamaktadır (Vandamme et al., 1996; Cavalier-Smith, 2002). Karşılaştırmalı 16S rRNA gen dizi analizleri modern taksonominin vazgeçilmezleri arasındadır. 2000'li yıllardan itibaren PCR kullanımının ve DNA dizilemenin yaygınlaşmasının sonucu olarak 16S rRNA gen 
bölgesinin dizilenmesi klinik mikrobiyoloji laboratuarlarında bakteriyal izolatların doğru şekilde tanımlanmasında ve yeni bakteriyal izolatların literatüre kazandırılmasında kilit nokta olmuştur. Acidithiobacillus cinsine ait 2 izolatın 16S rDNA gen bölgesi filogenetik analizinde 1185 nt'lik bir bölgede kiyaslanan G1 izolatının, 10 nükleotid fark ve \% 99.1 benzerlik ile Asidithiobacillus thiooxidans Y11596'ya benzediği tespit edilmiştir; G2 izolatı 1185 nt'lik bir bölgede karşılaştırıldı̆̆ında, 2 nükleotid farkı ve \% 99.7 benzerlik gösteren Acidithiobacillus ferrooxidans FJ194545'e benzediği tespit edilmiştir.

$\mathrm{Bu}$ filogenetik ağaç içerisinde Acidithiobacillus türleri güçlü bir homoloji ile kümelenmiş olup diş grup olarak seçilen Thermithiobacillus tepidarius türü ile ayrı bir kladda yer alması ve kendi aralarında güçlü bir homoloji oluşturması bu çalışmanın güvenilir olduğunu desteklemektedir. Çalışmamızda G1 suşu Asidithiobacillus thiooxidans ve G2 suşu Acidithiobacillus ferrooxidans olarak teşhis edilip bazı ektraselüler hidrolitik enzim kabiliyetleri ortaya çıkarılmıştır.

\section{Kaynaklar}

Bellenberg, S., Barthen, R., Boretska, M., Zhang, R., Sand, W., \& Vera, M. (2015). Manipulation of pyrite colonization and leaching by ironoxidizing Acidithiobacillus species. Applied and Environmental Microbiology, 99, 1435-1449.

Busse, H.J., Denner, E.B.M., \& Lubitz, W. (1996). Classification and identification of bacteria: Current approaches to an old problem. Overview of methods used in bacterial systematics. Journal of Biotechnology, 47, 3-38.

Cavalier-Smith, T. (2002). The neomuran origin of archaebacteria, the negibacterial root of the universal tree and bacterial megaclassification. International Journal of Systematic and Evolutionary Microbiology, 52, 7-76

Gonzalez-Toril, E., Llobet-Brossa, E., Casamayor, E.O., Amann, R., \& Amils, R. (2003). Microbial Ecology of An Extreme Acidic Environment, The Tinto River. Applied and Environmental Microbiology, 69(8), 4853-4865.

Hedrich, S., \& Johnson, D.B. (2013). Acidithiobacillus ferridurans, sp. nov.; an Acidophilic Iron, Sulfur and Hydrogen-metabolizing Chemolithotrophic Gammaproteobacterium. International Journal of Systematic and Evolutionary Microbiology, 63, 4018-4025.

Holt, J.G., Krieg, N.R., Sneath, P.H.A., Staley, J.T., \& Williams, S.T. (1994). Bergey's Manual of Determinative Bacteriology, 9th ed. Baltimore: Williams \& Wilkins.

Janeta Starosvetsky A., Udy Zukerman B., Robert H., \& Armon A. (2012). A simple medium modification for isolation, growth and enumeration of Acidithiobacillus thiooxidans (syn. Thiobacillus thiooxidans) from water samples. Journal of Microbiological Methods, 92, 178-182.

Kamimura, K., Higashino, E., Moriya, S., \& Sugio, T. (2003). Marine acidophilic sulfur- oxidizing bacterium requiring salts for the oxidation of reduced inorganic sulfur compounds. Extremophiles, 9599.

Karavaiko, G.I., Turova, T.P., Kondrateva, T.F., Lysenko, A.M., Kolganova, T.V., Ageeva, S. N., Muntyan, L.N., \& Pivovarova, T.A. (2003). Phylogenetic heterogeneity of the species Acidithiobacillus ferrooxidians. International Journal of Systematic and Evolutionary Microbiology, 53, 113-119.

Khan, S., Haq, F., Hasan, F., Saeed, K., \& Ullah, R. (2012). Growth and biochemical activities of Acidithiobacillus thiooxidans collected from black shale. Journal of Microbiology Research, 2(4), 78-83.

Lane, D.J., Stahl, D.A., Olsen, G.J., Heller, D.J., \& Pace, N.R. (1985). Phylogenetic analysis of the genera Thiobacillus and Thiomicrospira by $5 S$ rRNA sequences. Journal Bacteriology, 163, 75-81.

Rawlings, D. E. (1997). Biomining: Theory, Microbes and Industrial Processes, Berlin: Springer-Verlag.
Rawlings, D.E. (2005). Characteristics and adaptability of iron and sulfuroxidizing microorganisms used for the recovery of metals from minerals and their concentrates. Microbial Cell Factories, 4, 13.

Starosvetsky, J., Zukerman, U., \& Armon, R.H. (2013). A simple medium modification for isolation, growth and enumeration of Acidithiobacillus thiooxidans (syn. Thiobacillus thiooxidans) from water samples. Journal of Microbiological Methods, 92(2), 178-182.

Valenzuela L., Chi A., Beard S., Orell A., Guiliani N., \& Shabanowitz J. (2006). Genomics, metagenomics and proteomics in biomining microorganisms. Biotechnology Advances, 24, 197-211.

Van den Burg, B. (2003). Extromophiles as a source for novel enzyme. Current Opinion in Microbiology, 6, 213-218.

Vandamme, P., Pot, B., Gillis, M., de Vos, P., Kersters, K., \& Swings, J. (1996). Polyphasic taxonomy, a consensus approach to bacterial systematics. Microbiological Reviews, 60(2), 407-438. 